\title{
INVENTARISASI DAN ANALISIS PENOKOHAN NASKAH HIKAYAT AMIR HAMZAH
}

\author{
Prima Hariyanto \\ Kantor Bahasa Kepulauan Bangka Belitung \\ Kompleks Perkantoran dan Permukiman Terpadu Pemerintah Provinsi \\ Jalan Pulau Bangka, Airitam, Pangkalpinang \\ Pos-el: patriyawhura@gmail.com
}

\begin{abstract}
Abstrak
Indonesia memiliki banyak peninggalan naskah yang tidak tahan waktu dan rentan terhadap perubahan suhu sehingga mudah sekali menjadi rusak atau pun lapuk. Oleh karena itu, perlu diadakan pengalih aksaraan dan penelitian terhadap naskah-naskah tersebut. Salah satu naskah yang ada dalam khasanah pernaskahan nusantara adalah Hikayat Amir Hamzah, yakni naskah yang bernuansa agama Islam. Naskah ini berisi cerita kepahlawanan Amir Hamzah yang sering berperang membela agama Islam.Tulisan ini bertujuan menginventarisasi naskah sehingga jumlah naskah ini dapat diketahui, menyajikan suntingan teks, dan menganalisis penokohan Amir Hamzah dalam naskah ini. Metode yang digunakan dalam penelitian iniadalah metode deskriptif dan kajianpustaka. Langkah-langkah penelitian yang dilakukan meliputi pencarian data, pengalihaksaraan data, dan penganalisisan data. Naskah Hikayat Amir Hamzah berjumlah enam belas naskah. Jumlah ini belum termasuk naskah-naskah yang belum didata dan didaftar di dalam katalog. Di dalam naskah ini terdapat banyak peristiwa yang berhubungan dengan nilai-nilai Islam, yaitu dalam bentuk pengajaran dan teladan, misalnya nasihat yang mengingatkan kita untuk bersikap ikhlas, tidak berkhianat, takabur, riak, dan lupa kepada kebesaran Allah.
\end{abstract}

Kata Kunci: naskah, hikayat, Amir Hamzah, inventarisasi, Melayu Klasik

\section{The Inventory and Character Analysis in Hikayat Amir Hamzah}

\begin{abstract}
Indonesia has many manuscripts that cannot stand the time and are susceptible to temperature changes, making it easy to be damaged or rotten. These are the reasons why it is necessary to arrange an arbitration and research upon these texts. One of the manuscripts that exist in the archipelago treasury is Hikayat Amir Hamzah, which contains a nuanced of the Islamic religion. This manuscript consists of the story of the heroism of Amir Hamzah who often fought to defend Islam. This paper aims to inventory the manuscripts so that the number of these manuscripts is acknowledged, presented the text editing, and the analysis of the characterization of Amir Hamzah. The method used in this research is descriptive method and literature review. The research steps undertaken include data searching, data outsourcing, and data analysis. There are sixteen manuscripts of ofHikayat Amir Hamzah. This does not include the texts that have not been recorded and listed in the catalog. There are many events related to Islamic values in this text, in the form of teaching and example given, such as the advice that reminds us to be sincere, not to betray, arrogant, ripple, and forget the greatness of Allah.
\end{abstract}

Keywords: manuscript, hikayat, Amir Hamzah, inventory, Classical Malay

\section{PENDAHULUAN}

Salah satu peninggalan tertulis nenek moyang kita adalah naskah, yaitu tulisan tangan yang dibuat di atas media yang ada pada saat itu, seperti lontar, daluang, kertas eropa, kulit kayu, bambu, tulang, dan 
sebagainya. Indonesia banyak memiliki peninggalan naskah dari zaman dahulu yang tersimpan di berbagai perpustakaan dan museum serta tempat lain.

Selain itu, banyak juga naskah yang disimpan di perpustakaan negara lain, sebagai contoh banyak naskah Melayu yang disimpan di perpustakaan Leiden. Usaha yang dilakukan pemerintah Indonesia dalam menjaga, mengumpulkan, dan memelihara naskah-naskah yang masih ada di Perpustakaan Nasional RI merupakan suatu usaha yang perlu mendapat perhatian dari berbagai pihak agar hasil yang diperoleh dapat maksimal (Munawar \& Noegraha, 1997).

Mengingat keadaan naskah yang tidak tahan waktu dan rentan terhadap perubahan suhu sehingga mudah sekali rusak ataupun lapuk, perlu dilakukan pengaalihaksaraan dan penelitian terhadap naskah-naskah tersebut. Penelitian dan pengalihaksaraan ini bertujuan agar teks (kandungan naskah) tidak hilang percuma karena rusaknya naskah. Kita ketahuibahwadalam teks tersebut terkandung kekayaan pikiran masyarakat, adat-istiadat, kepercayaan, keadaan sosial masyarakat, kepribadian individu, hubungan antarindividu, dan sistem nilai yang berlaku di dalam masyarakat pendukungnya pada masanya.

Salah satu peninggalannaskah yang ada dalam khasanah pernaskahan nusantara adalah naskah yang bernuansa agama Islam. Tema mengenai proses masuknya agama Islam masuk ke nusantara masih menjadi perdebatan para ahli. Namun, pada umumnya berpendapat bahwa masuknya Islam ke nusantara melalui Gujarat, India, bukan langsung dari Arab. Bukti tertua masuknya Islam di Indonesia adalah batu nisan seorang wanita Islam yang berasal dari Leren (Gresik) yang bertahun 1082 dan bernama Fatimah binti Maimun ibn Hibatullah (Fang, 1991).

Bersamaan dengan masuknya agama Islam di Melayu, masuk pula kebudayaan, kesusastraan, dan bahasa Arab dan Persia. Hal ini diikuti dengan masuknya tulisan dan kosakata Arab. Masuknya kata-kata
Arab dalam bahasa Melayu sebagian besar melalui proses asimilasi dan adaptasi fonemis dan morfemis.

Karya-karya kesusasteraan Melayu pengaruh Islam dituliskan oleh para penulis Melayu Islam dengan tujuan menjadi media menyampaikan pengajaran Islam kepada pembaca. Hal ini disebabkan oleh eratnya hubungan antara kesusasteraan dan masyarakat Melayu tradisional. Oleh karena itu, para pengembang budaya dan agama Islam mengambil kesempatan ini untuk mengembangkan agama Islam melalui kesusasteraan (Hamid, 1983).

Hasil-hasil kesusasteraan lama Melayu, khususnya yang berbentuk hikayat berunsur Islam pada masa Islam mulai berkembang di Nusantara diduga sebagian besar merupakan terjemahan atau saduran dari cerita-cerita dari Persia. Hal ini disebabkan oleh Malaka yang telah menjadi pusat pengembang agama Islam di nusantara dan alim ulama dari Arab, Persia, dan tanah Hindi. Dari sinilah pengaruh Persia mulai masuk ke kebudayaan masyarakat Melayu. Tidak hanya bidang kesusasteraan, tetapi juga adat istiadat raja-raja Melayu, bahasa, dan agama (Ahmad, 1987).

"Hikayat Amir Hamzah" merupakan salah satu naskah yang bernuansa Islam, yaitu berisi cerita kepahlawanan Amir Hamzah yang sering berperang membela agama Islam. Dalam cerita ini, Amir Hamzah digambarkan sebagai sosok pahlawan yang sangat berjasa bagi perkembangan dan penyebaran ajaran Islam. Oleh karena itu, naskah ini menarik untuk dibahas lebih lanjut. Selainitu, kandungan naskah akan dapat dinikmati masyarakat secara luas. Berdasarkan latar belakang yang telah diungkapkan di atas, masalah yang akan dibahas dalam penelitian ini adalah berapa naskah yang terkandung dalam "Hikayat Amir Hamzah"dan bagaimana penokohan dalam naskah tersebut? 


\section{TEORI}

Hikayat adalah suatu istilah dalam bahasa Arab yang berarti cerita. Hikayat merupakan salah satu bentuk prosa Arab yang berkembang pada zaman Jahiliyah dan mengisahkan cerita bercorak dongeng dan legenda yang mengagung-agungkan tokoh pahlawan bagi suku Arab dalam perang saudara yang sering terjadi di sana (Hamid, 1983).

Perbincangan tentang sastra Melayu Klasik bernuansa Islam mulai hangat ketika Shahnon Ahmad menerbitkan makalahnya berjudul "Sastra Islam" di Majalah Dewan Bahasa, Kuala Lumpur, Juli 1977. Akhirnya, Majalah Dewan Sastera mengadakan Forum Sastra Islam sebagai tempat diskusi. Sepanjang tahun 1983 terjadilah polemik antara Shahnon Ahmad dan Kassim Ahmad di Majalah Dewan Sastera. Dari polemik tersebut muncullah beberapa pendapat tentang sastra Islam, yaitu mendukung nilai-nilai Islam, berdasarkan kisah-kisah yang ada dalam Quran dan Hadist, serta merupakan hasil tulisan yang berdasarkan tauhid (Fang, 1991).

\section{Kategori Naskah}

Kesusasteraan Melayu lama bercorak Islam khususnya yang berbentuk hikayat mempunyai hubungan erat dengan kesusasteraan Islam yang muncul di Arab sejak zaman permulaan Islam.

Dengan demikian, dapat disimpulkan bahwa sastra Islam adalah sastra tentang orang Islam dan segala amal salehnya. Sastra Melayu Islam adalah sastra orang Islam yang ditulis di dalam bahasa Melayu. Sebagian besar sastra ini merupakan hasil terjemahan atau saduran dari bahasa Arab atau Parsi dan tidak diketahui nama pengarang dan waktu penulisannya. $R$. Roolvink membagi sastra pengaruh Islam menjadi 5 kategori sebagai berikut.

\section{Cerita Al-Quran}

Cerita Al-Quran adalah cerita yang bersifat memberi pengajaran moral (didaktis). Melalui cerita ini, umat Islam diharapkan dapat mengambil pelajaran tentang perbuatan mana yang diridai dan dimurkai oleh Allah. Dalam bahasa Melayu, cerita Al-Quran disebut dengan "Kisah AlAnbiya". Salah satu "Kisah Al-Anbiya" adalah yang diterjemahkan oleh Haji Azhari Khalid yang memiliki jalan cerita yang sama dengan "Suratul Anbiya".

\section{Cerita Nabi Muhammad}

Cerita Nabi Muhammad dibagi lagi menjadi tiga jenis. Pertama, cerita yang mengisahkan riwayat Nabdi dari lahir hingga wafat. $\mathrm{K}$

emungkinan cerita ini berasal dari Sastra Sirah (riwayat hidup Nabi Muhammad) yang disusun sesudah Nabi wafat. Kedua, cerita yang mengisahkan mukjizat Nabi yang bertujuan mengagung-agungkan kemuliaan Nabi Muhammad sebagai nabi akhir zaman. Ketiga, cerita maghazi yaitu cerita yang mengisahkan peperangan yang dilakukan nabi untuk mengembangkan agama Islam.

\section{Cerita Sahabat Nabi Muhammad}

Sahabat atau al-shahabat adalah istilah Islam yang berarti orang-orang yang rapat sekali dengan Nabi yang kemudian maknanya diperluas menjadi orang-orang yang pernah bertemu dan bercakap dengan Nabi.

\section{Cerita Pahlawan Islam}

Cerita ini mengisahkan tokoh-tokoh sejarah yang berjasa terhadap perkembangan agama Islam atau tokoh yang pernah melakukan perbuatan yang menakjubkan. Sebagian besar cerita ini berasal dari Arab atau Parsi.

\section{Sastra Kitab}

Sastra ini biasanya disadur dari bahasa Arab oleh orang Indonesia di Mekah dan Madinah. Hal-hal yang dibahas adalah semua segi dalam agama Islam, seperti Quran, taksir, tajwid, hadis, arkan al-islam, fikh, dan usul al-fikh. 


\section{Ciri-Ciri Kategori Naskah}

Amir Hamzah adalah salah satu paman Nabi Muhammad yang awalnya memusuhi Nabi dan kemudian bertaubat hingga menjadi pahlawan Islam yang terkenal, terutama dalam Perang Badar dan Uhud. Amir Hamzah tewas ditikam oleh hamba Habsyi yang dihasut oleh ibu Muawiyah. Bangsa Parsi sangat menghormati Amir Hamzah sehingga dibuatlah hikayat tentang tokoh ini.

"Hikayat Amir Hamzah"memiliki terjemahan dalam berbagai bahasa. Terjemahan yang paling tua adalah dalam bahasa Arab. Terjemahan lainnya adalah dalam bahasa India (Hindustani), Benggali, dan beberapa bahasa daerah di Nusantara. Dalam bahasa Bugis diceritakan kematian Amir Hamzah dan Nabi Muhammad serta perlawanan Muhammad Hanfiah menuntut pembalasan. Versi bahasa Jawa yang juga menjadi sumber salinan versi Sunda dan Bali disebut dengan nama Menak yang artinya pahlawan. Cerita Menak terus berkembang hingga menjadi cerita yang sangat luas dan rumit jalan ceritanya. Cerita Menak juga menjadi sumber cerita dalam Wayang Golek.

Pemilihan dan penerimaan karangan Islam yang pertama dalam sastra Melayu disebabkan oleh adanya ciri-ciri yang dapat mendekatkannya dengan karya-karya dari masa sebelumnya dan karena cara-cara dakwahnya yang populer. Oleh karena itu, naskah jenis ini dikaji tidak secara kronologis, tetapi atas dasar bagaimana penting dan nyatanya unsur-unsur Islam yang terkandung di dalamnya, termasuk masalah-masalah Islam yang pokok.

Menurut Fang, dalam bukunya Sejarah Kesusastraan Melayu Klasik, Jilid 1 disebutkan bahwa "Hikayat Amir Hamzah" termasuk dalam kesusasteraan zaman Islam kategori cerita pahlawan Islam. Hal ini dapat dilihat dari banyaknya unsur-unsur agama Islam yang terkandung di dalam naskah ini. Selain itu, unsur kepahlawanan Amir Hamzah sangat menonjol dalam naskah ini. Amir Hamzah diceritakan sebagai seorang pahlawan
Islam yang sangat gagah berani dan sulit dikalahkan. Jasa Amir Hamzah juga begitu besar dalam perkembangan dan penyebaran Islam. Amir Hamzah telah menaklukkan negeri-negeri dan umat yang enggan masuk Islam(Fang, 1991).

Di dalam naskah ini terdapat banyak peristiwa yang berhubungan dengan nilainilai Islam, yaitu dalam bentuk pengajaran dan teladan. Sebagai contoh, nasihat yang mengingatkan kita untuk bersikap ikhlas, tidak khianat, takabur, riak, dan lupa kepada kebesaran Allah Swt. Hal ini dialami oleh Amir Hamzah. Dengan sombongnya Amir Hamzah tidak mengucapkan kalimat insya Allah ketika pergi ke Bukit Qaf. Sebagai akibatnya, waktu selama 18 hari yang dianggap ia butuhkan untuk mendaki Bukit Qaf ternyata berlarut hingga 18 tahun.

Hal ini juga dialami oleh Putri Mihrnigar yang mendapat surat dari Khoja Buzurjumhur Hakim, seorang menteri Raja Nusyirwan. Putri memuji-muji Khoja Buzurjumhur Hakim dengan berlebihan. Kemudian ia teringat akan kebesaran Allah dan ia pun segera beristigfar dan bertaubat kerena telah memuji mahluk Allah melebihi pujian terhadap Allah.

Mengenai kebesaran, keagungan, dan kekayaan di dunia ini tergambar dalam peristiwa Raja Nusyirwan. Raja Nusyirwan adalah raja yang teragung dan terkaya pada masanya dengan gelarnya Raja Masyrik dan Maghrib. Atas kehendak Allah, Raja Nusyirwan jatuh miskin. Ia bekerja sebagai pencari kayu bakar untuk medapat makanan hingga akhirnya ia ditolong oleh Amir Hamzah.

Dalam hikayat ini, juga diceritakan tentang Raja Syamsul Alam yang mengaku dirinya Tuhan yang telah menciptakan tujuh lapis langit, bintang, bulan, malaikat, dan sebagainya. Dengan kehendak Allah, ia dengan mudah dikalahkan dan tewas di tangan Amir Hamzah.

Sebagaimana halnya dengan hasil kesusasteraan Melayu Lama lainnya, pengarang "Hikayat Amir Hamzah" tidak mencatatkan namanya. Hal ini disebabkan 
karena hasil kesusasteraan Melayu Lama dianggap sebagai milik masyarakat sehingga penulis tidak perlu menuliskan namanya. Selain itu, penulis yang mengubah suatu karya tidak mau namanya dikenal dan terlibat dalam suatu perkara yang mungkin menyinggung pemerintah.

Penulis kesusasteraan Melayu bercorak Islam memiliki alasan lain selain alasan di atas. Pada umumnya, kesusasteraan Melayu bercorak Islam merupakan saduran dari bahasa Arab atau Parsi. Oleh karena itu, penulis merasa tidak berhak mencatatkan pada hasil karyanya karena karya tersebut bukan murni hasil buah pikirannya. Selain itu, kesusasteraan Melayu bercorak Islam berisi cerita yang berdasarkan riwayat seorang tokoh Islam atau peristiwa sejarah Islam sehingga penulis menganggap bahwa cerita itu bukan miliknya, melainkan milik umat Islam. Alasan lainnya adalah karena karyakarya tersebut ditulis untuk beribadah kepada Allah sehingga tidak layak jika harus memamerkan namanya. Hal seperti ini dianggap riak dan tidak ikhlas.

Sebuah karya pasti memiliki tujuan yang ingin dicapai oleh penulisnya. Begitu pula dengan kesusasteraan Melayu bercorak Islam tentang pahlawan Islam, terutama "Hikayat Amir Hamzah". Dalam tradisi masyarakat Melayu, hikayat yang populer akan dibacakan pada suatu majelis. Oleh karena itu, para penulis karya-karya ini juga ingin menyebarkan nilai-nilai Islam melalui cerita kepahlawanan yang sangat disukai oleh masyarakat Melayu. Selain itu, cerita kepahlawanan ditulis juga untuk memperkenalkan tokoh hero dari kebudayaan Islam. Hal ini ditujukan untuk mengambil alih kedudukan dan kemasyhuran tokoh-tokoh pahlawan dari kebudayaan lama, yaitu tokoh-tokoh dalam kebudayaan Hindu seperti Pandawa dan Seri Rama.

Naskah "Hikayat Amir Hamzah" yang tertulis dalam aksara Arab Melayu atau aksara Jawi ini telah banyak dibahas oleh para ilmuwan dan peneliti, baik dalam maupun luar negeri. Hal ini disebabkan oleh terkenalnya naskah ini dan banyak diminati oleh masyarakat. Berikut ini adalah beberapa peneliti yang pernah membahas naskah "Hikayat Amir Hamzah". Pertama, Winstedt. Winstedt berpendapat bahwa "Hikayat Amir Hamzah" sudah ditulis sejak tahun 1536, abad XV atau permulaan abad XVI. Pendapat ini didasarkan pada naskah "Sejarah Melayu" (cerita ke-34) yang menyatakan bahwa ketika Kerajaan Malaka akan berperang melawan Portugis pada tahun 1511, hulubalang Melayu meminta "Hikayat Muhammad Hanafiah"kepada Sultan Ahmad. Akan tetapi, Sultan Ahmad memberikan "Hikayat Amir Hamzah" dan berharap anak buahnya akan berani seperti Amir Hamzah(Braginsky, 1998). Peneliti kedua adalah Hooykass. Berkaitan dengan pendapat Winstedt, Hooykaas berpendapat ada dua kemungkinan. Penyebutan "Hikayat Amir Hamzah" dalam "Sejarah Melayu" mungkin hanya anakronisme atau tambahan kemudian. Dalam sastra Bali, terdapat pula cerita Amir Hamzah dalam bahasa Jawa Tengah-an yang sudah beberapa abad usianya. Hal ini dibuktikan oleh kenyataan bahwa sastra Islam biasanya ditulis dalam bahasa Melayu dan baru diterjemahkan ke dalam bahasa daerah lainnya. Jika cerita Amir Hamzah dari bahasa Melayu diterjemahkan dalam bahasa Jawa dan diterjemahkan lagi dalam bahasa Bali, cerita ini dapat dipastikan sudah tua usianya.

Di dalam "Hikayat Amir Hamzah" juga banyak digambarkan dengan jelas daerah-daerah di Asia. Penggambaran Asia hanya dapat dilakukan sebelum abad XVII karena sejak abad itu, bangsa Barat telah menerapkan monopoli perdagangan sehingga pengenalan terhadap daerah di Asia ketika itu sangat tidak mungkin. Selain itu, "Hikayat Amir Hamzah" sangat terpengaruh oleh suasana Syi'ah. Aliran Syi'ah merupakan aliran agama Islam yang paling awal masuk ke nusantara yang berasal dari Gujarat, India. Dengan demikian, sastra yang terpengaruh oleh 
aliran Syi'ah merupakan sastra dari masa yang tua. Berdasarkan penjelasan di atas, Hooykaas menyimpulkan bahwa "Hikayat Amir Hamzah" adalah sastra Islam yang tertua(Braginsky, 1998).Penelitiketiga, S. Van Ronkel.Van Ronkel menjadikan "Hikayat Amir Hamzah" sebagai bahan disertasinya dengan judul "De Roman van Amir Hamzah", Leiden, (1895). Ronkel meneliti dua buah naskah "Hikayat Amir Hamzah" yang ada di Leiden, yaitu naskah A (1697) dan naskah B (1698). Naskah tersebut terdiri atas 91 cerita dan masingmasing terdiri atas 1.225 halaman dan 1.843 halaman. Berdasarkan penelitian yang ia lakukan, Ronkel menyimpulkan bahwa "Hikayat Amir Hamzah" bukan berasal dari bahasa Arab seperti yang dikatakan oleh peneliti lain, melainkan langsung berasal dari bahasa Persia.

Pendapat ini didasarkan pada beberapa kenyataan. Pertama, baik versi Persia maupun Melayu menyebut Abdul Muttalib sebagai ayah Hamzah. Dalam versi Arab, Hamzah adalah anak Kinana. Kedua, pembagian bab versi Melayu sama dengan versi Persia. Ketiga, sebagian kata pendahuluan versi Melayu dalam bahasa Persia atauseringdisebutjugabahasaParsi. Keempat, banyak kata-kata dan sajak Persia terdapat dalam versi Melayu. Kelima, jalan cerita versi Persia dan Melayu sama. Keenam, jika dalam versi Persia ada sepatah kata Arab tipikal, kata Arab itu juga terdapat dalam versi Melayu. Van Ronkel juga berpendapat bahwa versi asli "Hikayat Amir Hamzah" adalah kumpulan dari berbagai cerita dan dongeng yang memuliakan agama Islam serta memuji pahlawan-pahlawan Islam. Menurut Van Ronkel, Menak yang merupakan khasanah sastra Jawa adalah saduran dari "Hikayat Amir Hamzah" versi bahasa Melayu. Akan tetapi, isinya lebih luas dari bahasa Melayu karena orang Jawa gemar mengembangkan dan meluaskan cerita yang mereka baca(Ronkel, 1909). Selainitu, Newbold, dalam Political and Statistical Account of the Brit. Sattlement in the Straits of Malacca II, halaman 318, menyatakan bahwa "Hikayat Amir Hamzah" diambil dari bahasa Arab. Hal ini sejalan dengan pendapat Dr. de Hollander yang terdapat dalam Handleiding bij de beoefening der Maleische Taal-en Letterkunde, Cetakan V, halaman 331.

Niemann dalam Bloemlezing uit Mal. Geschriften I, halaman 31 (Cetakan IV) memiliki pendapat lain. Ia menyatakan bahwa "Hikayat Amir Hamzah" berasal dari Parsi. Hal ini sejalan dengan pendapat Pijnappel dalam Bijdragen tot de Taal Land en Volkenkunde van Ned Indie, 1870, halaman 167.

Snouck Hurgronje dalam De Atjehers II, halaman 183 berpendapat bahwa "Hikayat Amir Hamzah" disusun berdasaarkan naskah Persia. Naskah tersebut sampai ke Melayu melalui India Selatan.

Sehubungan dengan adanya "Serat Menak" dalam kesusasteraan Jawa, Vreede-dalam katalog tentang naskahnaskah Jawa dan Madura yang ada di Universiteitsbibliotheek, Leidenmenyatakan bahwa "Serat Menak" dan "Hikayat Amir Hamzah" mempunyai hubungan yang erat.

\section{METODE}

Data yang digunakan dalam tulisan ini berasal dari naskah"Hikayat Amir Hamzah"yang disimpan di Perpustakaan Nasional RI. Penjelasan lebih lanjut dari naskah ini terdapat dalam deskripsi naskah pada subbab selanjutnya.

Dalam penelitian ini, penulis menggunakan metode deskriptif dan kajian pustaka. Penulis mencari sumber data penelitian, yaitu naskah "Hikayat Amir Hamzah" kemudian membuat suntingan teksnya menggunakan metode landasan. Langkah-langkah penelitian yang dilakukan meliputi pencarian data, pengalihaksaraan data, dan penganalisisan data(Lubis, 1996).

Langkah pertama adalah mencari dan menginventarisasikan naskah. Setelah ditemukan, naskah tersebut diteliti berdasarkan keadaan fisiknya. Langkah ini 
adalah implementasi dari ilmu kodikologi, yaitu ilmu yang mempelajari bentuk dan keadaan fisik naskah.

Langkah kedua adalah mengalihaksarakan naskah yang telah ditemukandariaksara Arab Jawikeaksara Latin. Dalam hal ini, tidak dialihaksarakan secarakeseluruhan isi naskah, tetapi hanya sepuluh halaman awal dari dua naskah yang diteliti. Langkah terakhir adalah membuat suntingan naskah dan membandingkan kedua naskah yang diteliti.

Dalam meneliti dan menganalisis naskah "Hikayat Amir Hamzah", digunakan metode kritis. Hal ini disebabkanolehkeadaan naskah ini meskipun merupakan naskah yang berjumlah lebih dari satu, naskah yang dapat digunakan dalam penelitian hanya satu naskah. Oleh karena itu, hanya dapat dibuat edisi teks berdasarkan naskahyang masih dapat diteliti tersebut. Metode kritis merupakan salah satu metode yang dapat digunakan dalam meneliti naskah tunggal. Metode ini memperbaiki teks naskah yang diteliti (Robson, 1994).

Kesalahan yang disengaja maupun tidak disengaja diperbaiki sesuai dengan ejaan yang berlaku sekarang, yaitu PedomanUmumEjaanBahasa Indonesia (PUEBI). Dengan cara demikian, diharapkan pembaca yang awam dengan naskah kuno dapat memahami kandungan naskah tersebut. Oleh karena itu, dari penelitian yang menggunakan metode ini dihasilkanlah sebuah naskah, salinan naskah, atau transliterasi yang sudah bebas dari kesalahan.

Edisi kritis dari suatu naskah lebih banyak membantu para pembaca. Pembaca dibantu mengatasi kesulitan yang berhubungan dengan teks tersebut dalamhal interpretasi. "Kritis" berarti penyunting mengidentifikasi sendiri bagian dalam teks yang mungkin terdapat masalah dan menawarkan jalan keluar. Terdapat dua alternatif untuk memecahkan masalah ini. Pertama, bila penyunting merasa bahwa ada kesalahan dalam teks tersebut, ia dapat memberikan tanda yang mengacu pada aparatus kritis. Ia menyarankan bacaan yang lebih baik. Kedua, pada bagian-bagian yang terdapat kesalahan, penyunting dapat memasukkan koreksi ke dalam teks tersebut dengan tanda yang mengacu pada aparatus kritis. Bacaan asli didaftar dan ditandai sebagai naskah (Robson, 1994).

\section{HASIL DAN PEMBAHASAN Inventarisasi Naskah}

Naskah "Hikayat Amir Hamzah" merupakan salah satu naskah yang berjumlah lebih dari satu. Naskah ini tersebar di beberapa negara di dunia, yaitu sebagai berikut.

\section{Indonesia}

Naskah "Hikayat Amir Hamzah" yang terdapat di Indonesia disimpan oleh Perpustakaan Nasional RI. Naskahnaskahtersebutadalahsebagaiberikut.

(a) ML. 23 selanjutnya disebut Naskah $\mathrm{A}$;

(b) ML. 672 (Br. 145) selanjutnya disebut Naskah B; dan

(c) Cs. 138 selanjutnya disebut Naskah C.

Naskah tersebut terdaftar dalam Katalog Induk Naskah-Naskah Nusantara: Perpustakaan Nasional Republik Indonesia yang disusun T.E. Behrend(Behren, 1998), Katalogus Koleksi Naskah Melayu Museum Pusat Departemen $P$ dan $K$ yang disusun oleh M. Amir Sutaarga, dkk. (Sutaarga, 1972), dan Catalogus der Maleische Handsscriften in het Museum van het Bataviaasch Genootschap van Kunsten en Weten-Schappen yang disusun oleh S. Ronkel(Ronkel, 1909).

\section{Malaysia}

Naskah "Hikayat Amir Hamzah" yang terdapat Malaysia disimpan oleh Dewan Bahasa dan Pustaka. Naskah-naskah tersebut adalah sebagai berikut. Naskah F, $\mathrm{G}$, dan $\mathrm{H}$ merupakan naskah cap batu (naskah cetak). 
(a) Cod DBP MSS 4 selanjutnya disebut Naskah D;

(b) Cod DBP MSS 121 selanjutnya disebut Naskah E;

(c) Cod DBP MSS 4 (a) selanjutnya disebut Naskah F;

(d) Cod DBP MSS 4 (b) selanjutnya disebut Naskah G; dan

(e) Cod DBP MSS 4 (c) selanjutnya disebut Naskah $\mathrm{H}$.

Naskah tersebut terdaftar dalam Hikayat Amir Hamzah: Diselenggarakan oleh A. Samad Ahmad yang disusun oleh A. Samad Ahmad(Ahmad, 1987).

\section{Perancis}

Naskah "Hikayat Amir Hamzah" yang terdapat di Perancis disimpan oleh Bibliotheque Municipale Tournus. Naskah "Hikayat Amir Hamzah" ini berkode i.i. 101 h. dan selanjutnya disebut Naskah I. Naskah tersebut terdaftar dalam Katalog Manuskrip Melayu di Perancis (Siri Bibliografi Manuskrip No. 9)(Penyusun, 1991).

\section{Inggris}

Naskah "Hikayat Amir Hamzah" yang terdapat di Inggris disimpan di Cambridge University Library. Naskah-naskah tersebut adalah sebagai berikut.

(a) Add. 3778 selanjutnya disebut Naskah J;

(b) Add. 3784 selanjutnya disebut Naskah K;

(c) Or. 846 selanjutnya disebut Naskah L; dan

(d) Rafles Malay 56 selanjutnya disebut Naskah M.

Naskah tersebut terdaftar dalam London Oriental Bibliographies - Volume 5: Indonesian Manuscripts in Great Britain yang disusun oleh M.C. Ricklefs dan P. Voorhoeve(Ricklefs \& Voorhoeve, 1977).

\section{Belanda}

Naskah "Hikayat Amir Hamzah" yang terdapat di Inggris disimpan di Leiden.
Naskah-naskah tersebut adalah sebagai berikut.

(a) Cod.Or.1697 selanjutnya disebut Naskah N;

(b) Cod.Or.1698 selanjutnya disebut Naskah O; dan

(c) Cod.Or.2020 selanjutnya disebut Naskah P.

Naskah tersebut terdaftar dalam Catalogue of Malay, Miangkabau, and South Sumatran in The Netherland Volume One yang disusun oleh Tengku Iskandar(Iskandar, 1999).

Berdasarkan uraian di atas, dapat disimpulkan bahwa "Hikayat Amir Hamzah" berjumlah enambelas naskah. Naskah ini belum termasuk naskah-naskah yang belum didata dan didaftar di dalam katalog. Ada kemungkinan terdapat naskah yang disimpan secara pribadi oleh masyarakat. Keenam belas naskah yang telah didaftar tersebut berada di perpustakaan di enam negara, yaitu PNRI (3 naskah), Dewan Bahasa dan Pustaka, Malaysia (5 naskah), Bibliotheque Municipale Tournus, Perancis (1 naskah), Cambridge University Library, Inggris (4 naskah), dan Legatum Warnerianum, Leiden University Library, Belanda (3 naskah).

\section{Suntingan Teks dan Deskripsi Naskah}

Di bawah ini, dideskripsikan keadaan naskah-secara langsung dari naskah aslinya - sebanyak tiga buah naskah, yaitu yang terdapat di Perpustakaan Nasional Republik Indonesia. Deskripsi suntingannaskah yang lainnya, diambil dari keterangan di dalam katalog, bukan langsung dari naskahnya.

\section{Suntingan Naskah A}

Naskah yang berjudul "Hikayat Amir Hamzah dan Syair Haji Ali" ini disimpan di Perpustakaan Nasional Republik Indonesia (PNRI) dengan nomor ML23, [R\#320,509], Rol (MF 115.01, 57, 01). Akan tetapi, pada catatan pemilik, naskah ini berjudul "Hikayat Amiroel Mokminina Hamzah en Sjair Makhatoel Managari”. 
Rol film naskah ini sudah rusak sehingga tidak dapat dicetak. Keadaan naskah tersebut saat ini sudah kurang baik. Halaman pelindung di awal dan akhir naskah sudah terlepas dari penjilidan. Di halaman pelindung akhir naskah terdapat catatan naskah yang menjelaskan kepemilikan naskah yang berbunyi "Bat. Gen. v VkW Mal. Ms. 23. Hikayat Amiroel Mokminina Hamzah en Sjair Makhatoel Managari. Dr M.J.A. va. Chijs di Padang. Batavia, 1866."

Kertas yang digunakan adalah kertas eropa dengan garis tebal tipis di setiap halamannya. Ukuran kertasnya adalah 30,5 $\mathrm{cm} \times 18 \mathrm{~cm}$. Naskah ini terdiri atas 96 halaman yang terdiri atas 88 halaman berupa hikayat dan 8 halaman berupa syair. Tiap halaman terdiri atas 43 baris dengan pias halaman: atas $2 \mathrm{~cm}$, bawah $2,5 \mathrm{~cm}$, kanan $3 \mathrm{~cm}$, dan kiri $2 \mathrm{~cm}$. Tinta yang digunakan untuk menulis naskah ini adalah tinta hitam. Di dalam naskah ini tidak ditemukan iluminasi, ilustrasi, dan catchword. Penomoran halamannya ditulis dengan pensil dan kemungkinan merupakan tambahan dari peneliti sebelumya. Naskah ini terdiri atas 8 kuras.

Sampul naskah ini berbahan dasar karton berwarna coklat dengan ukuran 30,5 $\mathrm{cm} \times 18 \mathrm{~cm}$. Pengikatnya berupa benang. Di beberapa tempat ditemukan rubrikasi dengan warna merah yang selalu menandai kata alkisah. Bahasa yang digunakan adalah bahasa Melayu dengan huruf Arab Melayu. Cap air (watermark) bergambar singa bermahkota berdiri dengan dua kaki belakangnya. Kaki depannya membawa pedang yang diarahkan ke atas (kaki kanan) dan anak panah (kaki kiri). Singa tersebut berada di dalam lingkaran bermahkota yang bertuliskan maakt magt pro patria eendragt. Di akhir naskah, ditemukan kolofon yang berbunyi "Pada Hikayat Amir Hamzah kepada tahun $11 \wedge 90$ Hijrah Nabi Muhammad salallahu alaihi wasalam. Pada bulan Januari empat hari bulan tahun 1864."

\section{Suntingan Naskah B}

Naskah yang berjudul "Hikayat Amir Hamzah"ini disimpan di Perpustakaan Nasional Republik Indonesia (PNRI) dengan nomor ML. 672 (Br. 145). Naskah ini terdiri atas dua jilid. Jilid pertama terdiri atas 253 halaman. Tiap halaman terdiri atas 23-25 baris. Akan tetapi, naskah jilid pertama ini sudah tidak ada lagi di PNRI. Jilid kedua terdiri atas 214 halaman. Tiap halaman terdiri atas 25 baris. Huruf yang digunakan adalah huruf Arab dengan tulisan yang kurang jelas dan sulit dibaca.

Ukuran halaman kedua naskah ini adalah 28,3 cm x 17,5 cm, tetapi di dalam Katalog Induk Naskah-Naskah Nusantara: Perpustakaan Nasional Republik Indonesia. Jilid IV, disebutkan bahwa naskah ini berukuran $28 \mathrm{~cm} \times 18 \mathrm{~cm}$. Kertas yang digunakan adalah kertas eropa dan cap kertas (watermark) tidak terlihat jelas karena tulisannya sudah agak luntur. Kedua naskah ini memiliki halaman pelindung di awal dan akhir naskah. Penjilidannya sudah rusak. Bahan sampul yang digunakan adalah kertas karton warna coklat.

Naskah ini mirip dengan naskah yang ada di Leiden yang bernomor Cod.Or.1697. Letak perbedaannya adalah pada naskah di Leiden, tidak terdapat cerita tentang kematian Amr Ibn Umayya. Naskah ini telah banyak dibicarakan oleh Hooykaas dalam Literatuur in Maleis en Indonesisch(Hooykaas, 1952)dan Winstedt dalam A History of Malay Literature(Winstedt, 1939).

\section{Suntingan Naskah C}

Naskah ini berjudul "Hikayat Amir Hamzah". Dalam Katalogus Koleksi Naskah Melayu Museum Pusat Departemen $P$ dan $K$, disebutkan bahwa naskah ini terdiri atas 248 halaman, berbahasa Melayu, dan beraksara Arab. Ukuran kertas yang digunakan 25 x $25 \mathrm{~cm}$ dan setiap halaman terdiri atas 18 baris. Akan tetapi, naskahinitidakditemukandi Perpusatakaan Nasional Republik 
Indonesia. Pihak PNRI tidak dapat menjelaskan keberadaan naskah tersebut. Mereka hanya menyebutkan bahwa naskah ini kemungkinan hilang saat dipindahkan.

\section{Suntingan Naskah D}

Naskah ini bernomor Cod DBP MSS 4dan sekarang disimpan oleh Dewan Bahasa dan Pustaka Malaysia. Naskah yang terdiri atas 314 halaman ini keadaannya sudah rusak. Banyak kertas di bagian awal dan akhir terlepas dari kurasnya. Naskah ini berukuran 40 x $25 \mathrm{~cm}$ dan setiap halaman terdiri atas 37 baris. Naskah ini merupakan hadiah dari Tengku Zahrah binti Tengku Kassim untuk Dewan Bahasa dan Pustaka yang diberikan pada tanggal 23 November 1962. Kertas yang akhir yang berisi kolofon sudah hilang sehingga tidak diketahui waktu penulisan naskah ini.

\section{Suntingan Naskah E}

Naskah ini bernomor Cod DBP MSS 121. Naskah ini sekarang disimpan oleh Dewan Bahasa dan Pustaka Malaysia. Naskah yang berjudul "Hikayat Amirul Mukminin Hamzah"ini terdiri atas 583 halaman. Setiap lembar naskah ini terdiri atas 20 baris dan tiap baris terdiri atas kurang lebih 15 kata. Keadaan naskah ini sudah sangat parah dan tidak berjilid. Menurut kolofonnya, naskah ini selesai disalin oleh Muhammad bin Mohd. Amin pada tahun 1291 H (1874 M) di Pulau Pinang. Hikayat ini awalnya merupakan milik Encik Muhammad Bakar bin Mohd. Amin.

\section{SuntinganNaskah F}

Naskah ini bernomor Cod DBP MSS 4 (a). Naskah ini sekarang disimpan oleh Dewan Bahasa dan Pustaka Malaysia. Naskah ini merupakan naskah cap batu (naskah cetak). Di halaman judul naskah ini tertulis, "Bahawa inilah hikayat yang bernama Amir Hamzah yang amat indah-indah ceritanya, lagi amat ajaib-ajaib sebutannya. Dimaklumkan kepada sekalian tuan-tuan, maka adalah hikayat yang tersebut ini dan Hikayat Sultan Bustamam, jika tuan-tuan berkehendak boleh dapat beli di kedai
Pawan Muhammad Syarif Haji Abdul Kadir Company, iaitu di Jalan Achin Street, Masjid Melayu, No. 4C, Pulau Pinang."

Naskah ini sudah rusak dan halaman pada bagian akhir sudah hilang. Naskah ini diperoleh Dewan Pustaka dan Bahasa Malaysia dari Tengku Kalsom Bt. Sultan Abdul Hamid, Kedah.

\section{Suntingan Naskah G}

Naskah yang bernomor Cod DBP MSS 4 (b), sekarang disimpan oleh Dewan Bahasa dan Pustaka Malaysia. Naskah ini merupakan naskah cap batu yang merupakan hadiah dari Tengku Zam-Zam binti Tengku Haji Osman, Kelang. Naskah ini disusun dan diatur oleh Aliman bin Mahmud. Naskah ini selesai ditulis pada tanggal 14 Zulhijah 1355 (Februari 1837) oleh Raja Ahmad bin Cik. Naskah ini dicap dan dikeluarkan oleh Singapura Jawi Press No. 242, Lorong Engku Aman, Geylang, Singapura. Naskah ini masih disimpan dalam keadaan yang baik dengan penjilidan yang masih sempurna.

\section{Suntingan Naskah H}

Naskah ini bernomor Cod DBP MSS 4 (c) dan sekarang disimpan oleh Dewan Bahasa dan Pustaka Malaysia. Naskah ini merupakan naskah cap batu yang terdiri atas dua jilid dan merupakan hadiah dari Tengku Zam-Zam binti Tengku Haji Osman, Kelang. Naskah ini diperoleh dari Mohd. Arsyad bin Abdullah.

Jilid pertama naskah ini keadaannya cukup baik, tetapi halaman awal dan akhir telah rusak. Naskah ini memuat halaman 1-290. Jilid kedua naskah ini memuat halaman 291-576. Kondisinyamasih dalam keadaan baik dan terjilid dengan sempurna. Pada bagian akhir tertulis, "Telah selesai daripada menulis pada 9 Ramadhan, 1360, bersamaan dengan 30 September 1841. Dicap dan dikeluarkan oleh Singapura Jawi Press No. 675, Geylang Road, Singapura. Diatur dan disusun oleh Aliman bin Mahmud." 


\section{Suntingan Naskah I}

Naskah "Hikayat Amir Hamzah" yang dimiliki oleh Perancis disimpan oleh Bibliotheque Municipale Tournus. Naskah ini terdapat dalam Katalog Manuskrip Melayu di Perancis (Siri Bibliografi Manuskrip No. 9). Naskah "Hikayat Amir Hamzah" ini berkode i.i. $101 \mathrm{~h}$. dan terdiri atas 105 halaman. Hikayat ini menceritakan kegagahan dan keperwiraan Amir Hamzah; seorang pejuang Islam yang ulung di zaman awal kebangkitan Islam. Naskah ini bermula dengan kisah Alqas, menteri membunuh Khoja Bahti Jamal dan diakhiri dengan Landuhur yang ditawan oleh anak raja.

\section{Suntingan Naskah J}

Naskah ini bernomor Add. 3778 dan berjudul "Hikayat Amir Hamzah" Naskah ini disimpan di disimpan di Cambridge University Library dan terdaftar dalam London Oriental Bibliographies - volume 5: Indonesian Manuscripts in Great Britain. Naskah ini menggunakan kertas yang berukuran $30 \times 17 \mathrm{~cm}$.

\section{SuntinganNaskah K}

Naskah ini bernomor Add. 3784 dan berjudul "Hikayat Amir Hamzah" serta menggunakan kertas eropa berukuran 25,5 x 20,5 cm. Naskah ini terdiri atas 4 jilid yang diberi kode Add. 3784 A, Add. 3784 B, Add. 3784 C, dan Add. 3784 D. Naskah ini disimpan di disimpan di Cambridge University Library dan terdaftar dalam London Oriental Bibliographies - volume 5: Indonesian Manuscripts in Great Britain.

\section{Suntingan Naskah L}

Naskah ini bernomor Or. 846 dan berjudul "Hikayat Amir Hamzah" Naskah ini disimpan di disimpan di Cambridge University Library dan terdaftar dalam London Oriental Bibliographies - volume 5: Indonesian Manuscripts in Great Britain. Naskah ini menggunakan blue europe paper berukuran 31 x $21 \mathrm{~cm}$.
Menurut kolofonnya, naskah ini disalin oleh Encik Husain bin Ismail.

\section{Suntingan Naskah M}

Naskah ini bernomor Rafles Malay 56 dan berjudul "Hikayat Badi' az-Zaman". Namun, di bagian belakang terdapat naskah "Hikayat Amir Hamzah". Naskah ini menggunakan white europe paper dan blue europe paper. Naskah ini disimpan di Cambridge University Library dan terdaftar dalam London Oriental Bibliographies -Volume 5: Indonesian Manuscripts in Great Britain.

\section{Suntingan Naskah $\mathbf{N}$}

Naskah ini bernomor Cod.Or. 1698 dan berjudul "Hikayat Amir Hamza". Naskah yang merupakan naskah tulisan tangan Muhammad Cing Sa'idullahini, pernah digunakan sebagai bahan penelitian Van Ronkel pada tahun 1895 sebagai naskah B. Naskah ini terdiri atas empat jilid.

Jilid I terdiri atas 384 halaman dan memuat halaman $1-392$, tetapi mulai halaman 322 dan seterusnya terdapat kesalahan, yaitu ditulis dengan halaman 330 dan seterusnya. Setiap halaman terdiri atas 13 baris. Naskah ini berukuran 18,5 x $13 \mathrm{~cm}$ dan menggunakan media dutch laid paper. WatermarksbertuliskanPro Patria with H.F. DE CHARRO. Naskah ini ditulis dengan menggunakan tinta hitam dan terdapat rubrikasi.

Jilid II memuat halaman 393-813, tetapi pada halaman setelah 488 ditulis dengan halaman 500. Naskah ini berukuran $18,5 \times 13 \mathrm{~cm}$ dan ditulis menggunakan tinta hitam. Setiap halaman terdiri atas 13 baris dan terdapat rubrikasi. Watermarks bertuliskan Pro Patria with BLAU \& BRIEL.

Jilid III memuat halaman 814-1331, tetapi halaman 866 dan 1166 tidak ada. Naskah ini berukuran 18,5 x $13 \mathrm{~cm}$ dan ditulis menggunakan tinta hitam. Setiap halaman terdiri atas 13 baris dan terdapat rubrikasi. Watermarks bertuliskanPro Patria with BLAU \& BRIEL. 
Jilid IV memuat halaman 1332 - 1843 . Naskah ini berukuran 18,5 x $13 \mathrm{~cm}$ dan ditulis menggunakan tinta hitam. Setiap halaman terdiri atas 13 baris dan terdapat rubrikasi. Watermarks bertuliskan Pro Patria with BLAU \& BRIEL.Naskah ini disimpan di Legatum Warnerianum, Leiden University Library dan terdaftar dalamCatalogue of Malay, Miangkabau, and South Sumatran in The Netherland Volume One.

\section{Suntingan Naskah O}

Naskah ini bernomor Cod.Or. 1698 dan berjudul "Hikayat Amir Hamzah".Naskah ini merupakan naskah tulisan tangan Muhammad Cing Sa'idullah dan pernah digunakan sebagai bahan penelitian Van Ronkel pada tahun 1895 sebagai naskah A. Naskah ini terdiri atas 2 jilid dan diduga merupakan salinan naskah Cod.Or. 1698.

Naskah ini berukuran 19 x $15,5 \mathrm{~cm}$. Jilid pertama terdiri atas 328 halaman, sedangkan jilid II terdiri atas 281 halaman. Naskah ini menggunakan media dutch laid paper dan ditulis menggunakan tinta hitam serta terdapat rubrikasi. Watermarks jilid pertama bertuliskan Pro Patria and Vrijheid, sedangkan jilid kedua bertuliskan Pro Patria and KONING \& DESJARDJIN. Naskah ini disimpan di LegatumWarnerianum, Leiden University Library dan terdaftar dalamCatalogue of Malay, Miangkabau, and South Sumatran in The Netherland Volume One.

\section{Suntingan Naskah $P$}

Naskah ini bernomor Cod.Or. 2020 dan berjudul "Hikayat Amir Hamza". Naskah ini terdiri atas 641 halaman. Ukuran kertas yang digunakan untuk halaman $1-449$ adalah $22 \times 17 \mathrm{~cm}$, sedangkan halaman 450-641 adalah 21 x $17 \mathrm{~cm}$. Tiap halaman terdiri atas 13 baris. Naskah ini ditulis dengan menggunakan tinta hitam di atas media european laid paper. Naskah ini pernah digunakan oleh Van Ronkel sebagai naskah $\mathrm{C}$ dalam penelitiannya pada tahun 1895. Naskah ini disimpan di LegatumWarnerianum, Leiden University
Library dan terdaftar dalamCatalogue of Malay, Miangkabau, and South Sumatran in The Netherland Volume One.

\section{Perbandingan Naskah}

Seperti telah dijelaskan sebelumnya, naskah "Hikayat Amir Hamzah" yang terdapat di Indonesia berjumlah 3 naskah, yaitu naskah A (ML.23), naskah B (ML.672/Br.145), dan naskah C (Cs.138). Pada awalnya, tulisan ini akan membandingkan naskah A dan naskah B. Hal ini disebabkan oleh keadaan naskah $\mathrm{C}$ yang tidak memungkinkan untuk dilihat dan diteliti lebih lanjut. Akan tetapi, setelah diteliti lebihlanjut, naskah B yang hanya tersisa jilid keduanya saja tidak dapat dibandingkan dengan naskah A. Oleh karena itu, teks yang dipaparkan dalam tulisan ini hanya berdasarkan naskah A.

Meskipun demikian, karena "Hikayat Amir Hamzah" telah ada edisi teksnya, yaitu berupa transliterasi naskah ini, dalam tulisan ini pula akan ditunjukkan perbandingan teks naskah A dengan transliterasi naskah Malaysia. Transliterasi naskah Malaysia ini dibuat oleh A. Samad Ahmad dan telah diterbitkan oleh Dewan Bahasa dan Pustaka Kementerian Pelajaran Malaysia dengan judul Hikayat Amir Hamzah: Diselenggarakan oleh A. Samad Ahmad. Transliterasi yang dibuat oleh Ahmad tersebut merupakan edisi teks dari naskah D (Cod DBP MSS 4) dan naskah E (Cod DBP MSS 121). Untuk mempermudah perbandingan kedua naskah tersebut, selanjutnya akan disebut edisi teks naskah Malaysia dengan naskah Q.

Berdasarkan jumlah halaman yang terkandung, dapat dipastikan kepadatan cerita di naskah A dan naskah Q berbeda. Naskah A hanya terdiri atas 96 halaman, sedangkan naskah Q yang merupakan edisi dari naskah D dan naskah E terdiri atas 314 dan 583 halaman. Dengan demikian, dapat ditarik kesimpulan sementara bahwa cerita di naskah A lebih padat daripada di naskah Q. 
Naskah A merupakan naskah yang diawali dengan kisah Zubin pergi ke negeri Kuhastana untuk menemui Raja Brahmana Arjasi. Kisah ini dilanjutkan dengan cerita perburuan rusa yang dilakukan oleh Amir Hamzah bersama laskarnya.

Naskah Q merupakan naskah yang cukup renggang ceritanya. Naskah ini diawali dengan mukadimah yang berisi ringkasan cerita yang diawali dengan kalimat "Bismillahirrahmanirrahim. Wabihi nasta'in billah alaiya." Di dalam mukadimah ini juga digambarkan sosok Amir Hamzah secara panjang lebar dan bahkan sering diulang-ulang. Amir Hamzah digambarkan sebagai sosok pahlawan yang gagah berani dan tak terkalahkan serta masyhur namanya di dunia.

Dalam naskah A, cerita dimulai ketika Amir Hamzah sudah dewasa dan memiliki istri. Di sini ia telah menjadi pahlawan yang diagung-agungkan oleh rakyatnya karena selalu dapat mengalahkan musuhnya. Hal ini sangat berbeda dengan naskah Q yang juga menceritakan kisah Amir Hamzah ketika dilahirkan, bahkan jauh sebelum dia dilahirkan.

Pada bagian awal, naskah Q berisi kisah kelahiran Khoja Buzurjumhur Hakim pada masa pemerintahan Raja Kobad Syahril. Setelah itu, diceritakan kelahiran Raja Nusyirwan Adil dan Khoja Buzurjumhur Hakim. Barulah. Kemudian, diceritakan kisah Raja Kobat Syahril, sebab Khoja Buzurjumhur Hakim dititahkan pergi ke Mekah, serta kelahiran Amir Hamzah dan Umar Umaiyah Zamhuri di Mekah.

Dengan demikian, dapat dikatakan bahwa naskah Q menceritakan kisah dua generasi sebelum Amir Hamzah, yaitu Raja Kobad Syahril dan anaknya, Raja Nusyirwan. Amir Hamzah seumuran Raja Nusyirwan. Ketika naskah A sudah menceritakan kepahlawanan Amir Hamzah, naskah Q baru bercerita tentang sejarah kelahiran Amir Hamzah, bahkan kisah tentang generasi sebelum Amir Hamzah. Naskah A memang merupakan naskah yang lebih padat dibandingkan dengan naskah Q.

\section{Ringkasan Isi Teks "Hikayat Amir Hamzah"}

Ringkasan cerita berikut ini merupakan ikhtisar yang dibuat oleh S. Van Ronkeldalam buku Sejarah Kesusastraan Melayu Klasik, Jilid 1, karya Liaw Yock Fang(Fang, 1991).

Negeri Medain diperintah oleh seorang raja bernama Kobad Syahriar dan perdana menteri bernama Khawajeh Alqasy. Suatu ketika, Khawajeh Alqasy membunuh Bekhti Jamal, teman dekatnya, untuk mendapatkan harta bendanya. Sebelum meninggal, Bekhti Jamal berpesan kepada Khawajeh Alqasy untuk menjaga istri Bekhti Jamal dan anak yang dikandungnnya.

Anak Bekhti Jamal lahir dan diberi nama Buzur Jamal. Pada umur sembilan tahun, dia sudah menjadi seorang ahli nujum yang pandai dan ingin mencari pembunuh ayahnya. Suatu ketika, Raja Kobad Syahriar bermimpi dan tidak dapat ditafsirkan oleh Alqasy. Raja meminta Buzur Jamal datang ke istana dan menafsirkan mimpinya. Buzur kemudian membeberkan segala kejahatan Alqasy sehingga Alqasy dihukum mati dan segala harta bendanya diberikan pada Buzur. Buzur akhirnya menjadi ahli nujum Raja Kobad Syahriar. Buzur meramalkan bahwa raja akan dikaruniai seorang anak yang sebaiknya diberi nama Nusyirwan dan musuh kerajaan akan datang dari Arab. Karena ketakutan terhadap hal itu, raja memerintahkan membunuh semua wanita yang hamil.

Di Mekah, Abdul Muttalib dikaruniai anak yang diberi nama Amir Hamzah (selanjutnya disebut Hamzah), sedangkan Omayya al-Darmri dikaruniai anak yang diberi nama Amir Ibn Omaya (selanjutnya disebut Amir). Buzur yang mendapat tugas membunuh semua wanita hamil dan bayi tidak 
membunuh kedua bayi tersebut. Di Negeri Medain, Raja Kobad telah mangkat dan digantikan oleh Nusyirwan. Bekhtek, anak Alqasy, diangkat menjadi menteri.

Ketika berumur tujuh tahun, Hamzah dan Amir sudah memiliki kekuatan yang luar biasa. Mereka mampu menewaskan pegulat yang tak terkalahkan. Mereka juga berguru pada seorang ahli pemanah. Hamzah mendapat panah Ishak dan kekuatannya bertambah. Di taman Sulaiman keduanya mendapat kuda yang hebat dan berbagai senjata.

Kekuatan yang mereka miliki digunakan untuk menolong orang lain. Mereka menyelamatkan upeti Mekah untuk Nusyirwan dari serangan penyamun Mokbil Halabi. Di Yaman, Hamzah mengalahkan Puteri Hamai Taif yang hanya mau menikah dengan orang yang mampu mengalahkannya. Namun, Hamzah tidak menikahinya dan memberikannya kepada Tauk Tariq yang sangat mencintainya. Hamzah juga mengalahkan Amir Ibnu Ma'di Karib yang kemudian menjadi pengawal Hamzah bersama keempat puluh saudaranya.

Mendengar keberanian Hamzah, Nusyirwan ingin bertemu dengannya. Seorang pahlawan Nusyirwan tidak menyukai hal itu sehingga Hamzah terpaksa mengalahkannya. Gustehem, pahlawan Nusyirwan yang lain berniat membunuh Hamzah, tetapi akhirnya dikalahkan oleh Hamzah.

Hamzah jatuh cinta pada Mihrnigar, putri Nusyirwan. Hal itu tidak disukai Nusyirwan sehingga ia mengirim anaknya untuk menangkap Hamzah. Akan tetapi, keduanya malah ditawan oleh Hamzah. Akhirnya, pada hari ketiga, kedua putra Nusyirwan dikembalikan.

Nusyirwan mendapat surat dari Raja Syelpal dari Serendib yang memberitahukan bahwa dirinya telah diusir dari kerajaan oleh seorang raksasa bernama Lendehur. Bekhti mengusulkan agar memberikan Mihrnigar kepada orang yang mampu mempersembahkan kepala Lendehur. Hal ini dimaksudkan agar Hamzah dibunuh oleh Lendehur. Hamzah pergi ke pulau kediaman Lendehur. Dalam perjalanan, hal-hal aneh terjadi. Hamzah juga mendapatkan jimat dari Adam, Ibrahim, Ismail, dan Sulaiman. Peperangan pun dimulai dan setelah tujuh belas hari berperang, Lendehur dapat dikalahkan oleh Hamzah.

Gustehem mengutus seorang perempuan untuk menyanyi dan meracuni Hamzah. Hamzah tertidur selama 40 hari. Lendehur yang telah masuk Islam mengusir Gustehem. Mengetahui korbannya masih hidup, Gustehem melarikan diri ke Zubin, Turkestan. Hamzah sembuh dan segera memulihkan kerajaan Syelpal. Hamzah kembali ke negerinya dengan membawa Lendehur.

Bekhtek mengingatkan bahwa syarat perkawinan Hamzah dengan Mihrnigar adalah kepala Lendehur. Lendehur bersedia kepalanya dipenggal. Ketika Nusyirwan memerintahkan memenggal kepala Lendehur, Hamzah memerintahkan Amir menangkap Bekhtek dan memukulnya bertalu-talu. Bekhtek menyuruh Nusyirwan mengelabuhi Hamzah dengan membunuh seorang wanita dan mengatakan Mihrnigar telah meninggal. Hal ini diketahui oleh Amir.

Bekhtek kembali berniat membunuh Hamzah dan menyuruh Nusyirwan mengadakan sayembara. Barang siapa mampu mengalahkan tiga orang raja yang tidak mau membayar upeti akan dikawinkan dengan Mihrnigar. Hamzah bersedia melaksanakan tugas itu. Qarun yang bertugas sebagai penunjuk jalan disuruh Bekhtek meracuninya, tetapi semuanya diketahui oleh Hamzah.

Di Yunan, Hamzah membunuh Adir, Raja Yunan. Semua kemenakan 
Adir masuk Islam. Di Rum, ia mengalahkan raja Rum yang kemudian bersama dengan semua kemenakannya masuk Islam. Di Mesir, Hamzah ditipu oleh Aziz dan dikurung di dalam sebuah pulau. Mokbil yang mendengar hal itu segera menuju pulau tersebut. Raja pulau tersebut telah menikah dengan putri Aziz yang bernama Zuhrah Banu. Ibrahim menampakkan diri dan menemui Zuhrah Banu. Kemudian, Zuhrah Banu membunuh suaminya dan mengembalikan senjata Hamzah. Aziz pun dibunuh oleh putrinya sendiri. Mereka segera kembali ke Mesir dan melangsungkan pernikahan Zuhrah Banu dan Mokbil setelah Zuhrah Banu masuk Islam.

Hamzah melawan Nusyirwan. Gustehem bersama anak-anaknya dibunuh oleh Hamzah. Hamzah sendiri dilukai oleh Zubin dan dibawa ke Mekah. Pada suatu ketika, Nusyirwan, Bekhtek, dan Zubin diculik oleh musuh. Setelah mengalami berbagai hal, mereka akhirnya dikembalikan.

Di Bukit Qaf, ada dua kota yang diperintah oleh peri Islam bernama Azra dan peri kafir bernama Ifrit. Ifrit mengusir Azra dari kerajaan. Hamzah datang dan membunuh Ifrit. Azra memberikan topi Sualiman yang ajaib kepada Hamzah. Dalam perjalanan pulang Hamzah tertidur dan ditangkap oleh Habra Diw, anak Ifrit. Hamzah kemudian membunuh Habra Diw. Hamzah jatuh cinta pada Asman, kemenakan raja, dan menikahinya. Dari perkawinan ini lahir seorang putri yang diberi nama Quraisy. Hamzah berkata bahwa kecantikan Quraisy seperti Mihrnigar. Asman cemburu dan pergi meninggalkan Hamzah. Hamzah mencari Asman hingga memasuki sebuah gua yang dihuni banyak jin dan mengusir mereka yang tinggal di sana. Hamzah sampai di sebuah taman yang sangat indah. Di sana ia diperdaya oleh seorang peri kafir dan seekor burung menyelamatkan Hamzah.
Semua penduduk kekurangan makanan. Amir ibn Ma'di Karib meminta makanan kepada para khalifah dan menangkis semua serangan perampok. Di sebuah negeri, Amir ibn Ma'di dipilih menjadi raja. Dia mengambil seorang permaisuri. Esok harinya, permaisuri mangkat. Hamzah muncul dan seluruh penduduk kota masuk Islam. Kemudian terjadilah peperangan. Tentara musuh dimusnahkan. Bekhtek, Zubin, dan Nusyirwan melarikan diri ke Homum, Damaskus. Hamzah mengirim utusan kepada Homum di Damaskus. Askar Damaskus tewas. Sementara itu, putri Nasir hamil dengan cara yang tidak wajar. Pada suatu malam, putri Nasir menemukan selimut Hamzah dan kemudian mengenakannya. Dengan serta merta, putri Nasir hamil dan melahirkan seorang anak yang diberi nama Omar ibn Hamzah.

Hamzah meminang Mihrnigar dan mendapat restu dari Nusyirwan. Bekhtek menganjurkan agar istana Zubin dirampok. Hamzah mengikuti saran itu dan semua harta bendanya dirampas habis. Kemenakan Gulrukh dijadikan istri Omar. Istri dan ibunya juga dijadikan istri oleh Amir ibn Ma'di Karib dan Amir.

Bekhtek melarikan diri ke Behman di Turkestan. Tentara Hamzah tiba dan terjadilah peperangan. Behman dan Bekhtek dapat dikalahkan. Hamzah yang mendengar Mekah dikepung oleh Syaddad Abu Omar Habsyi segera kembali dan mengalahkan musuh. Syahddad dapat dikalahkan dan masuk Islam. Syahddad menyerang Medain. Nusyirwan dan Bekhtek berhasil ditawan.

Kobad, anak Hamzah dibunuh oleh Zubin. Zubin diam-diam mendekati Mihrnigar dan membunuhnya. Hamzah sangat berduka atas kejadian tersebut. Qaren, anak raja Akko menculik dan memenjarakan Hamzah dan Mokbil. Saudara perempuan Qaren mendapat 
wahyu untuk membebaskan mereka. Hamzah dibebaskan dan Qaren dibunuh. Hamzah pun menikah dengan saudara perempuan Qaren. Alju-Syeh Gezi, Qimas, dan Keyus datang menyerang tentara Hamzah. Ketiganya dikalahkan dan masuk Islam. Hamzah juga jatuh cinta pada dan kawin dengan putri Gil-Sowar.

Seorang putri Cina, Urnekir yang cintanya ditolak Hamzah menjadi cemburu dan berniat membunuh Hamzah dan istri barunya. Rencana itu gagal dan Urnekir terbunuh oleh putri Gil-Sowar. Nusyirwan berduka karena kekasihnya, Urnekir, meninggal. Ia menyamar sebagai pedagang dan mengembara ke Negeri Cina. Dalam perjalanan ia dirampok. Nusyirwan bekerja sebagai penjaga api untuk mendapatkan makanan. Permaisuri menulis surat kepada Hamzah untuk mencari Nusyirwan. Sebagai rasa terima kasih, Hamzah dikawinkan dengan putri Nusyirwan. Bekhtek merasa iri dan berniat jahat kepada Hamzah.

Raja Malek dan Raja Erdebil, Cup Gurden, termakan hasutan Malek dan mengerahkan tentaranya untuk melawan Hamzah. Keduanya dapat dikalahkan dan masuk Islam. Putri Gil-Sowar telah melahirkan seorang anak yang tidak ingin dipelihara oleh Hamzah. Anak itu, Badi ul-Zaman dihanyutkan ke sungai dan dipelihara oleh Putri Asman di Bukit Qaf. Setelah dewasa, Badi pergi mencari ayahnya dan diterima. Amir sangat marah kepada Bekhtek yang menjadi biang keladi dari banyaknya pembunuhan. Ia menyamar sebagai seorang tukang masak dan membunuh Bekhtek.

Gawilingi mengirim Zerduhsht yang membawa pasukan harimau untuk menyerang tentara Hamzah. Pasukan harimau itu dihancurkan oleh Herum dan Amir. Gawilingi berhasil ditaklukkan Hamzah dan bertaubat. Zerduhsht terbakar dan mati di dalam kamarnya. Hamzah menemui Nabi
Muhammad dan belajar agama Islam. Hamzah pun menjalankan segala perintahnya. Muhammad mendapat kabar bahwa orang kafir sedang menghimpun kekuatan untuk melawannya. Akhirnya terjadilah peperangan. Gawilingi dibunuh oleh Pur Hindi. Hamzah marah dan membunuh Pur Hindi.

Ibu Pur Hindi mengumpulkan tentara dari Rum, Syam, Habsyi, dan Zengebar untuk menyerang tentara Hamzah. Harmuz juga membawa bala tentaranya yang begitu banyak untuk mengepung Mekah dan sampai di Bukit Uhud. Tentara Nabi Muhammad diporak-porandakan oleh tentara musuh. Satu per satu pahlwan Islam gugur, Lendehur, Sa'd ibn Omar, dan Amir Ibn Ma'di Karib. Kaki Ali kena panah dan gigi Nabi Muhammad pecah dua. Hamzah marah dan segera menyerang tentara musuh. Ia mengejar Hurmuz dan membunuhnya.

Hamzah mulai tidak tenang karena kasut kaki kudanya lepas. Ia teringat ramalan Buzur yang mengatakan bahwa ia akan mati jika kasut kaki kudanya lepas. Ibu Pur Hindi yang sudah lama mengintainya memotong kaki kuda Hamzah hingga Hamzah terjatuh dan kemudian Hamzah dibunuh. Ibu Pur Hindi teringat bahwa Hamzah memiliki seorang anak yang mungkin akan membalas dendam. Ia kemudian meminta maaf kepada Nabi Muhammad. Nabi pun memaafkannya.

Asman dan Quraisy datang dengan seribu peri dari Mekah dan meminta agar ibu Pur Hindi diserahkan kepada mereka. Pada waktu itu surat al-Jin diwahyukan. Nabi Muhammad menerangkan kepada putri Hamzah, jika Hamzah tidak meninggal, ia tidak dapat mencapai syahadat dan tinggal di surga. Nabi menyuruhnya memandang ke langit dan tampaklah Hamzah sedang duduk di surga dan sangat dimuliakan Allah. Asman dan Quraisy pun memuji Allah. 


\section{Analisis Penokohan Tokoh Amir Hamzah}

Amir Hamzah adalah salah satu pahlawan Islam yang sangat populer dengan kegagahan dan keperkasaannya melawan para musuh. Amir Hamzah adalah anak dari Abdul Mutalib yang dilahirkan pada tahun 569 M. Amir Hamzah merupakan paman Nabi Muhammad saw. dari pihak ibu. Ia juga saudara sesusu Nabi. Amir Hamzah tumbuh menjadi laki-laki yang kuat dan tangguh serta ditakuti oleh kaum Quraisy.

Seperti keluarga Nabi Muhammad yang lain, Amir Hamzah pada mulanya juga menentang ajaran Nabi. Ia tidak percaya dengan apa yang diajarkan oleh Nabi Muhammad. Akan tetapi, dengan kegigihan dan kesabaran Nabi Muhammad satu per satu orang di sekitar Nabi mengikuti ajarannya, termasuk Amir Hamzah. Amir Hamzah menjadi pengikut dan pengawal Nabi yang sangat tangguh. Ia selalu berada di barisan depan dalam peperangan melawan musuh. Amir Hamzah mendapat julukan "Harimau Allah" karena ketangguhannya.

Amir Hamzah sangat berjasa pada Perang Badar, yaitu perang antara kaum kafir Quraisy yang berjumlah 900-1.000 orang melawan pasukan Islam yang hanya berjumlah sepertiga dari pasukan Quraisy. Perang yang terjadi pada tahun 2 Hijriah $(624 \mathrm{M})$ ini dimenangi oleh umat Islam. Sebagai manusia biasa yang lemah di hadapan Tuhan, Amir Hamzah pun gugur di tangan kaum Quraisy dalam Perang Uhud pada tahun 3 Hijriah (625 M). Sejak itulah, Amir Hamzah dengan ketangguhannya menjadi legenda bagi umat Islam.

"Hikayat Amir Hamzah" menggambarkan watak Amir Hamzah sebagai paman Nabi Muhammad, yaitu Hamzah bin Abu Thalib. Sifat Amir Hamzah dalam hikayat ini agak berbeda dengan sifat Hamzah bin Abu Thalib yang sesungguhnya. Hamzah bin Abu Thalib merupakan paman Nabi yang pada mulanya termasuk golongan kaum yang menentang ajaran Nabi Muhammad dan kemudian sadar terhadap kebenaran ajaran yang dibawa Nabi. Hal ini berbeda dengan Amir Hamzah dalam "Hikayat Amir Hamzah" yang digambarkan sebagai penganut agama Nabi Ibrahim (yang berarti ia telah beragama Islam) sebelum ia menjadi pengikut Nabi Muhammad.

Dalam hikayat ini, Amir Hamzah digambarkan sebagai seorang laki-laki yang sangat kuat dan tak terkalahkan. Ketika Amir Hamzah berumur tujuh tahun, ia sudah mampu menewaskan seorang ahli gulat. Amir Hamzah juga merupakan seorang anak yang nakal. Ia suka mencuri telur ketika lapar dan menjual pakaian gurunya.

Setelah dewasa dan berguru ke banyak ahli, Amir Hamzah tumbuh menjadi orang yang baik hati dan suka menolong. Ia telah menyelamatkan upeti yang dibawa untuk Raja Nusyirwan yang akan dirampas penyamun. Amir Hamzah juga seorang pemaaf. Ia jarang sekali memiliki perasaan dendam terhadap seseorang. Bahkan, dalam peperangan melawan Lenduhur, Amir Hamzah menolong Gustehem yang hampir dibunuh Lenduhur. Gustehem merupakan musuh Amir Hamzah yang selalu berniat mencelakakannya.

Amir Hamzah adalah orang yang tidak pernah merasa putus asa. Hal ini tergambar dalam segala tindak tanduknya. Ia selalu berusaha untuk mengalahkan musuhnya dengan sekuat tenaga. Ia juga tak pernah berputus asa mendapatkan Putri Mihnigar. Amir Hamzah berusaha agar Raja Nusyirwan merestui hubungan mereka.

\section{Tanggapan Terhadap Teks"Hikayat Amir Hamzah"}

"Hikayat Amir Hamzah" merupakan sebuah kisah yang sangat populer dalam kebudayaan masyarakat Melayu. Kisah ini diwariskan secara turun-temurun sehingga sangat mungkin mengalami banyak perubahan, baik sedikit maupun banyak. Manuskrip-manuskrip cerita Amir Hamzah banyak terdapat dalam bahasa Arab dan Parsi. Manuskrip cerita Amir Hamzah 
dalam bahasa Arab yang berjudul "Sirat Hamzah" disimpan di perpustakaanperpustakaan di Gotha dan Paris. Dalam manuskrip tersebut tertulis penulisnya, yaitu Abu al-Ma'ali al-Kufti. Manuskrip cerita Amir Hamzah dalam bahasa Parsi berjudul "Dastani Amir Hamzah", "Qissah Amir Hamzah", "Asmar Hamzah", dan sebagainya. Pengarang Parsi yang dianggap menulis kisah ini adalah Jalal al Balkhi, Muhammad Abu al-Ma'ali dan lain-lain.

Sebagaimana telah dijelaskan sebelumnya, tokoh Amir Hamzah dalam "Hikayat Amir Hamzah" sedikit berbeda dengan tokoh Hamzah bin Abu Thalib. Dalam hikayat, Amir Hamzah digambarkan sebagai orang yang telah memeluk agama Islam sebelum menjadi pengikut Nabi Muhammad, sedangkan Hamzah bin Abu Thalib termasuk golongan yang pada awalnya menentang ajaran Nabi. Dengan demikian, dapat dikatakan bahwa "Hikayat Amir Hamzah" yang berisi perjuangan Amir Hamzah ini telah banyak diberi tambahan di sana-sini dengan berbagai kisah peperangan dan pengembaraan yang bercorak khayal dan fantasi.

Dalam hikayat ini juga diperlihatkan unsur yang menonjol mengenai perjuangan menyebarkan agama Islam. Di dalamnya digambarkan beberapa media yang digunakan untuk menyebarkan agama Islam, salah satunya yang dominan adalah dengan jalan peperangan. Perang Badar dan Perang Uhud adalah perang besar yang dilakukan oleh umat Islam untuk melawan kaum kafir Quraisy. Akan tetapi, dalam hikayat ini diceritakan banyak sekali peperangan yang dilakukan oleh Amir Hamzah dalam mengembangkan agama Islam. Menurut saya, hal ini bertentangan dengan ajaran Islam yang mencintai perdamaian. Dalam Quran disebutkan bahwa agama Islam merupakan rahmatal lil alamin dan disebarkan dengan cara yang damai.

Menurut Hamid, banyaknya peperangan yang diceritakan dan digambarkan dalam "Hikayat Amir Hamzah" hanya bertujuan untuk membangkitkan semangat keislaman dan menarik kegairahan para pembaca yang merupakan masyarakat Melayu yang menganut agama Islam. Selain banyaknya tambahan cerita peperangan tersebut, "Hikayat Amir Hamzah" juga dicampuradukkan dengan cerita tentang seorang pahlawan Parsi yang berjuang menentang kerajaan Abassiyah bernama Hamzah bin Abdullah. Hamzah bin Abdullah merupakan seorang pejuang yang gagah berani dan sangat populer di dalam masyarakat Parsi. Perwatakan Hamzah bin Abdullah dicampuradukkan dengan Hamzah bin Abu Thalib sehingga muncullah cerita bercorak Islam yang mengisahkan perjuangan seorang pahlawan Islam dan ditambah cerita-cerita bercorak fantasi tentang pengembaraan Amir Hamzah (Hamid, 1983).

\section{PENUTUP}

"Hikayat Amir Hamzah" merupakan salah satu naskah yang bernuansa Islam, yaitu berisi cerita kepahlawanan Amir Hamzah yang sering berperang membela agama Islam. Amir Hamzah adalah seorang pahlawan Islam yang sangat ditakuti kaum kafir Quraisy dan sangat populer di kalangan umat Islam.

Berdasarkan hasil inventarisasi, "Hikayat Amir Hamzah" berjumlah enam belas naskah. Naskah ini belum termasuk naskah-naskah yang belum didata dan didaftar di dalam katalog. Ada kemungkinan terdapat naskah yang disimpan secara pribadi oleh masyarakat. Ketiga belas naskah yang telah didaftar tersebut berada di perpustakaan di lima negara, yaitu PNRI (3 naskah), Dewan Bahasa dan Pustaka, Malaysia (5 naskah), Bibliotheque Municipale Tournus, Perancis (1 naskah), Cambridge University Library, Inggris (4 naskah), dan Legatum Warnerianum, Leiden University Library, Belanda (3 naskah).

Amir Hamzah adalah salah satu paman Nabi Muhammad yang awalnya memusuhi 
Nabi dan kemudian bertaubat hingga menjadi pahlawan Islam yang terkenal, terutama dalam Perang Badar dan Uhud. Jasa Amir Hamzah juga begitu besar dalam perkembangan dan penyebaran Islam. Amir Hamzah telah menaklukkan negerinegeri dan umat yang enggan masuk Islam. Amir Hamzah merupakan sosok pahlawan yang kuat, pemberani, tidak mudah putus asa, penolong, dan bukan pendendam.

Berdasarkan suntingan teks, di dalam naskah ini terdapat banyak peristiwa yang berhubungan dengan nilai-nilai Islam, yaitu dalam bentuk pengajaran dan teladan, misalnya nasihat yang mengingatkan kita untuk bersikap ikhlas, tidak khianat, takabur, riak, dan lupa kepada kebesaran Allah Swt.

Berdasarkan analisis penokohan, tokoh Amir Hamzah dalam hikayat ini dengan tokoh Hamzah bin Abu Thalib sedikit berbeda. Akan tetapi, banyak sekali hal yang dapat kita contoh dari keteladanan tokoh Amir Hamzah dalam hikayat ini, terutama keberaniannya dalam menghadapi apa pun, kecuali Allah Swt.

\section{DAFTAR PUSTAKA}

Ahmad, A. S. (1987). Hikayat Amir Hamzah: Diselenggarakan oleh A. Samad Ahmad. Kuala Lumpur: Dewan Bahasa dan Pustaka, Kementerian Pelajaran Malaysia.

Behren, T. (1998). Katalog Induk NaskahNaskah Nusantara: Perpustakaan Nasional Republik Indonesia. Jilid IV. Jakarta: Yayasan Obor Indonesia dan Ecole Française D'extreme Orient.

Braginsky. (1998). Yang Indah, Berfaedah dan Kamal: Sejarah Sastra Melayu dalam Abad 7-19. Jakarta: Indonesian-Netherlands Cooperation in Islamic Studies.

Fang, L. Y. (1991). Sejarah Kesusastraan Melayu Klasik Jilid I. Jakarta: Erlangga.
Hamid, I. (1983). Kesusasteraan Melayu Lama dari Warisan Peradaban Islam. Petaling Jaya, Selangor: Fajar Bakti SDN BHD.

Hooykaas, C. (1952). Literatuur in Maleis en Indonesisch. Groningen, Djakarta: J.B. Wolters.

Iskandar, T. (1999). Catalogue of Malay, Minangkabau, and South Sumatran in The Netherland Volume One. Leiden: University Leiden.

Lubis, N. (1996). Naskah, Teks dan Metode Penelitian Filologi. Jakarta: Forum Kajian Bahasa dan Sastra Arab, Fakultas Adab IAIN Syarif Hidayatullah.

Munawar, M., \& Noegraha, N. (1997). Khasanah Sastra Nusantara. In Tradisi Tulis Nusantara (p. 34). Jakarta: Masyarakat Pernaskahan Nusantara.

Penyusun, T. (1991). Katalog Manuskrip Melayu di Perancis (Siri Bibliografi Manuskrip No. 9). Kuala Lumpur: Perpustakaan Negara Malaysia.

Ricklefs, M. C., \& Voorhoeve, P. (1977). London Oriental Bibliographies volume 5 : Indonesian Manuscripts in Great Britain. London: Oxford University Press.

Robson, S. (1994). Prinsip-Prinsip Filologi Indonesia. Terj. Kentjanawati Gunawan. Jakarta: RUL.

Ronkel, P. S. (1909). Catalogus der Maleische Handsscriften in het Museum van het Bataviaasch Genootschap van Kunsten en Weten-Schappen. Batavia: Albrecht $\&$ co.

Sutaarga, M. A. (1972). Katalogus Koleksi Naskah Melayu Museum Pusat Departemen $P$ dan $K$. Jakarta: Proyek Inventarisasi dan Dokumentasi Kebudayaan Nasional, Direktorat Jendral Kebudayaan, Deperteman P dan K.

Winstedt, R. (1939). A History of Malay Literature. London: JMBRAS. 
Telaga Bahasa Vol.8, No.1, April 2020 